\title{
Public Opinion and Democratic Legitimacy in Africa
}

Revised Chapter Prepared for the Routledge Handbook of Democratization in Africa Gabrielle Lynch and Peter VonDoepp, eds.

Robert Mattes

University of Strathclyde

4 September 2018 


\section{Public Opinion and Democratic Legitimacy in Africa}

When the third wave of democracy washed across Africa in the early 1990s, leading Africanists openly questioned whether civil liberties, multi-party elections, and representative institutions held any real meaning for ordinary Africans. Many suggested that the reforms that restored political rights and civil liberties, and ushered in multi-party elections, had taken place simply as a function of economic crisis

(e.g. Bates 1994), or pressure from international actors such as the International Monetary Fund and World Bank (e.g. Munslow 1993; Young 1993; Nwajiaku 1994). Little attention, in contrast, was paid to the desires of Africans themselves.

In their landmark study of Africa's transitions, Michael Bratton and Nicolas van de Walle (1998) challenged these interpretations, producing clear evidence of the primacy of domestic protest in determining where these transitions took place, and where they succeeded. Yet several related and fundamental questions were still unanswered. Were the pro-democratic demands of students, church and civic groups, and labor unions driven simply by opposition to the continent's failed one party, military or big man regimes, or did they reflect explicit preferences for popular self-government? And if they did, did the views of those groups reflect a broader, heretofore unappreciated wellspring of support for democracy amongst the wider mass public? And lastly, if such support did exist, how extensive, firm, and informed was it?

Answers to these questions can now be found in a series of regular public opinion surveys of ordinary Africans conducted by Afrobarometer since 1999. Conducted initially in 12 sub-Saharan countries between 1999 and 2001 (Round 1) and progressively expanding to include, by 2014-2015, as many as 36 countries (Round 6), this project carries out face-to-face interviews with nationally representative samples, conducted in the language of the respondent's choice. In this chapter, I review what we have learnt from these surveys about ordinary Africans' support for various aspects of the democratic regime, and their orientations to the challenges of active citizenship. I then consider how Africans understand the concept of "democracy," and how they assess its actual performance. 
The key finding are as follows. Elected, representative democracy enjoys a widespread, though not overwhelmingly, positive image. However, while the median African supports democracy, and rejects presidential dictatorship, military rule, and the one-party state, when measured with single indicators, many Africans are inconsistent democrats, rejecting some elements of autocracy while expressing acquiescent or even anti-democratic sentiments on others. Thus, the proportion of respondents who demand democracy by providing consistently pro-democratic responses is less than one-half of all respondents. Moreover, while demand for democracy increased in the period between the surveys conducted in 2002-2003 and 2011-2013, it has declined in the most recent measurement point (20152016). And once we move beyond continental averages, we find enormous cross-national variation, as well as country paths over time, with some countries still displaying steady gains, but others in decline, and still others characterized by trendless variation.

Surveys have also found varying levels of support for key parts of the institutions of vertical and horizontal accountability. Compared to their levels of support for democracy, Africans are far less likely to see themselves as active principals, with a role to play in controlling the actions of their elected agents. At least part of this incomplete embrace of democratic politics and citizenship surely stems from how Africans understand democracy. While they articulate a surface understanding of democracy in terms of political procedure, they can be easily persuaded of alternative economic and substantive understandings of democracy. Thus, many apparently committed democrats express satisfaction with the performance of regimes that are only partially democratic, and the size of the proportion of dissatisfied democrats is too small in many places to push for the expansion of democracy, or to safeguard its erosion.

\section{Do Africans Want Democracy?}

While there are legitimate worries over what ordinary citizens understand by "democracy," and how this may "contaminate" responses to questions designed to tap support for liberal, electoral democracy (a subject to which we will turn later in this chapter), it is impossible to assess popular attitudes toward this form of political regime without actually using the word. Thus, we begin with a 
widely used survey question, first asked by Morlino and Montero (1995) that asks respondents: "Which of these three statements is closest to your own opinion?
A. Democracy is preferable to any other form of government.
B. In certain situations, a non-democratic government can be preferable. Or
C. To people like me, it doesn't matter what form of government we have.

In this question, and throughout the questionnaire, the word 'democracy' was offered in English and translated into a local language only if the respondent was unable to understand the English version. In the first round of Afrobarometer surveys, conducted from 1999-2001, ${ }^{1}$ more than two-thirds (69 percent) of all respondents across 12 countries said that "democracy is preferable to any other form of government." Flash forward to the most recent round of surveys conducted in 2014-2015 and we find that a very similar 67 percent provide the same response, even though that average was now based on results from 36 countries.

However, because some people might possess an attachment to the word "democracy" without a meaningful idea of what the concept entails (a point we will explore in greater detail on pp. XX to XX), Afrobarometer drew on the work of Richard Rose and his colleagues (Rose et al. 1998) to develop a series of items that assessed popular attitudes to democracy without using the "D-Word." These questions ask respondents whether they would support or oppose abandoning the present system of multi-party elections for a range of authoritarian alternatives, each of which have been experienced by many of the countries included in the survey.

There are many ways to govern a country. Would you disapprove or approve of the following alternatives?

-Only one political party is allowed to stand for election and hold office.

-The army comes in to govern the country.

-Election and Parliament are abolished so that the president can decide everything.

Substantially larger proportions of respondents reject non-democratic alternatives than embrace the term democracy. In the first round of surveys, from 1999 to 2001,83 percent rejected military rule, and 80 rejected presidential dictatorship. However, a significantly lower 70 percent adopted a negative view to one party rule. As of 2014-2015, the cross-national average level of rejection across 36 countries was 78 percent for both presidential dictatorship and the one-party 
rule, and 73 percent for military rule. Thus, based on this initial scan of continent-wide results, the median African appears to be strongly supportive of democracy, though they may be more certain about the type or regime they don't want, than the one they do.

\section{FIGURE 1 ABOUT HERE \\ ATTITUDES TOWARD DEMOCRATIC REGIME}

Overall levels of support are far more variable, however, when Africans are asked about specific dimensions of democratic politics. In terms of vertical accountability, a cross-continental average of 80 percent, as of 2014-2015, agree that leaders should be chosen "through regular, open and honest elections."2 Yet far fewer people are convinced that elections need to be organized along partisan lines: fewer than two-thirds (63 percent) agree that "many political parties are needed to make sure that we have real choices in who governs them." ${ }^{3}$ And when the idea of citizen influence over government is pitted against government effectiveness, barely one-half of all respondents (51 percent) say that "It is more important for citizens to be able to hold government accountable, even if it makes decisions more slowly." 4

While multi-party elections have been relatively easy to institutionalize, African polities still struggle to develop effective institutions of horizontal accountability that limit the power of "big man" presidents. Yet the fault does not necessarily lie with the electorate. While some have argued that Africans see political leaders in a paternalist light as extensions of the "father figure" (Schaffer 1998), there is strong, though far from consensual popular agreement with the idea of separation of powers and limitations on the power of the state and executive presidents. Three out of every four people (75 percent) believe that "the Constitution should limit the president to serving a maximum of two terms in office," and seven-in-ten (69 percent) believe "the news media should constantly investigate and report on corruption and the mistakes made by the government." ${ }^{\prime 6}$ In turn, around two-thirds (67 percent) agree that the elected members of parliament "should make the laws for this country, even if the President does not agree, $(67$ percent $),{ }^{7}$ that the "President must always obey the laws and the courts, even if he thinks they are wrong" (67 percent), ${ }^{8}$ and that the legislature "should ensure that the President explains to it on a 
regular basis how his government spends the taxpayers' money" (64 percent). ${ }^{9}$ However, just a little more than one-quarter (27 percent) say that "After losing an election, opposition parties should monitor and criticize the government in order to hold it accountable." ${ }^{10}$ This is a potentially significant flaw in public thinking that facilitates big man" dominance, since it is opposition parties who have the greatest incentive to drive legislative attempts to call the President to account.

FIGURE 2 ABOUT HERE

ATTITUDES TOWARD VERTICAL AND HORIZONTAL ACCOUNTABILITY

Perhaps the weakest area of African attitudes toward democracy can be found in responses to questions concerning individual citizenship and agency. Last asked in 2008-2009 (Round 4) in 20 countries, just 58 percent agreed with the statement that "Citizens should be more active in questioning the actions of leaders." ${ }^{11}$ Even fewer people see themselves as principals who control government representatives as their agents: in 2011-2013, as just 54 percent agreed that "Government is like an employee; the people should be the bosses who control the government," while a sizable minority (41 percent) believed that "People are like children; the government should take care of them like a parent." A different question, last asked in 2005-2006 (Round 3) in 18 countries, found an even split between those who agreed that "people should look after themselves and be responsible for their own success in life" (48 percent) and those who felt that "The government should bear the main responsibility for the well-being of people" (48 percent). Perhaps no result is more illustrative of a lack of citizen agency than the response to the question on who should be responsible, between elections, for ensuring that elected legislators and local councilors do their jobs. As of 2014-2015, just 37 percent chose the option of "the voters" when asked about parliament. Indeed, 29 percent said it was the job of the President, 16 percent pointed to the legislature itself, and 10 percent said it was the task of the political party (similar results emerged when asked about local councilors).

FIGURE 3 ABOUT HERE

ATTITUDES TOWARD CITIZENSHIP 


\section{Cross National Variation}

Thus far, we have focussed on producing a broad-brush portrait of the median African and restricted the analysis to cross-national averages. Yet these averages mask a large degree of variation countries. For instance, the continental average response to the question on whether "democracy is always preferable" suggests that the term enjoys a broadly, though certainly not overwhelmingly positive image across Africa. Yet support ranges widely from a high of more than eight-in-ten respondents in eight countries, including Burundi (86 percent), Senegal ( 85 percent), and Botswana (83 percent), downward sharply to less than 50 percent in Algeria (46 percent), Swaziland (45 percent), Mozambique (45 percent), and Sudan (44 percent). Rejection of presidential dictatorship varies from 93 percent in Senegal to just 35 percent in Mozambique. Opposition to military rule displays a similar range, from 91 percent in Kenya to just one-third of Egyptians (33 percent). And rejection of one-party rule similarly spans a 42 point range from 92 percent in Sierra Leone to 50 percent in Mozambique.

While the results to any single question on democratic attitudes provide us with an idea of the breadth of citizen support for democracy and its constituent parts, a better test of the depth of popular commitment is whether citizens offer consistently pro-democratic responses. Afrobarometer has developed such a measure that uses the questions on support for democracy and rejection of three authoritarian alternatives discussed above, an aggregate construct called popular demand for democracy. As of 1999-2001, 48 percent of all respondents were consistent democrats, across 12 countries. In 20142015, the figure stood at 43 percent across 26 countries, ranging from 74 percent in Mauritius to just 9 percent in Mozambique.

\section{FIGURE 4 ABOUT HERE DEMAND FOR DEMOCRACY}

\section{What Do Africans Understand As "Democracy"?}

We have now seen that fairly large majorities of Africans offer pro-democratic responses to a range of different, but not all, survey questions. Yet sceptics might argue that under-educated people, many living in rural areas with often limited access to critical electronic or print media, are insufficiently 
knowledgeable or experienced about democracy to offer meaningful assessments or preferences about political regimes. From a different perspective, others have argued that Africans have a unique understanding of democracy and political authority that departs in significant ways from western conceptions based on individual rights, and political procedures (Owusu 1992; Ake 1996; Osubu-Kle 2000; Schaffer 1998). What Africans understand as "democracy," thus, has been the object of regular enquiry in Afrobarometer surveys, though from differing methodological approaches. However, while these attempts have taught us a great deal, we lack a clear, stable answer. Much depends on question format and question wording.

\section{Open Ended Questions}

Several rounds of Afrobarometer surveys have included an open-ended question that asks respondents: "What, if anything does democracy mean to you?" and allows for up to three spontaneous responses, which are then coded into broader categories for analysis. The responses to this question appear to provide several important conclusions. First, while the vast majority of respondents are able to provide at least one response (78 percent across 12 countries in 1999-2001), ${ }^{12}$ a fifth of respondents (22 percent) could not. Moreover, the proportions of people able to offer even a second (14 percent) let alone a third (5 percent) response drop markedly.

Second, those respondents who can provide a spontaneous definition offer overwhelmingly positive views ( 73 percent of all respondents, and 93 percent of those able to provide an answer). Third, those who could provide an answer seemingly understood democracy through a largely liberal lens, defining democracy in terms of political procedures and political rights (Bratton and Mattes 2001; and for similar cross-continental conclusions, see Dalton, Shin and Jou 2001. In 1999-2001, one third (38 percent) provided an answer that referred to some area of "civil liberty" or "personal freedom" as one of three possible responses. The next most common responses were those referring to some element of "government by the people" (22 percent) or "voting," "elections" and "party competition" (9 percent). Much smaller proportions mentioned substantive outcomes such as "peace or unity" (7 percent), "equality and justice" (6 percent), or "socio-economic development," (4 percent). 


\section{Closed-Ended Questions}

Afrobarometer has also tested popular understandings of democracy through a series of different approaches using closed-ended questions. Some of these confirm the images generated by the open-ended approach, but others produce sharply diverging answers.

\section{Vignettes}

In Round 4, Afrobarometer examined shared understandings of democracy through a series of anchoring vignettes in which respondents were asked to compare hypothetical African regimes. This format provided responses broadly consistent with responses to open-ended questions: that is Africans tie their understanding of democracy to the quality of political procedures and electoral competition.
A. Abigail lives in a country with many political parties and free elections. Everyone is free to speak their minds about politics and to vote for the party of their choice. Elections sometimes lead to a change of ruling party. In your opinion, how much of a democracy is Abigail's country?
B. Bernard lives in a country with regular elections. It has one large political party and many small ones. People are free to express their opinions and to vote as they please. But so far, elections have not led to a change of ruling party. In your opinion, how much of a democracy is Bernard's country?
C. Cecilia lives in a country with regular elections. It has one big political party and many small ones. People afraid to express political opinions or to vote for the opposition. The opposition is so weak that it seems that it can never win an election. In your opinion, how much of a democracy is Cecilia's country?

Across 20 countries in 2008-2009, seven-in-ten Africans (76 percent) recognized Country A to be a "full democracy," or one with "minor problems, though one-in-ten (13 percent) said they did not know. In contrast, just 48 percent gave the same characterization to Country B, and only 13 percent called Country C a democracy. Indeed, 46 percent said flatly that Country C was "not a democracy," and 26 percent said it was a "democracy, with major problems" (Bratton 2010). These responses, then, appear to corroborate the view that Africans see democracy through a political lens.

\section{Agreement With Proffered Definitions}

An altogether different picture of African understandings of democracy emerges from a different approach, pursued in the first round of 12 surveys (1999-2001), that posed a series of close-ended statements about democracy and asked respondents whether each was "essential, important, not very important or not important at all." Respondents were told that: 
People associate democracy with many diverse meanings such as the ones I will mention now. In order for a society to be called democratic, is each of these essential, important, not very important, or not important at all to have?

-Majority Rule

-Regular Elections

-At Least 2 Political Parties Regularly Competing With Each Other Party Competition

-Complete Freedom for Anyone To Criticize Government

-Basic Necessities Like Food, Water and Shelter for Everyone

-Equality in Education

-Jobs for Everyone

-Small Income Gap Between Rich and Poor

In contrast to the open-ended items, responses to these questions suggest that Africans see democracy through a very substantive, and material lens. When reminded of the debate about democracy, respondents tended to give at least equal weight to both substantive economic outcomes and political procedures in two countries (Botswana and Zimbabwe). In seven other countries, however, respondents systematically emphasized the items on economic equality, and neglected the items on political procedures. In South Africa, for instance, an average of 60 percent said that socioeconomic goods were "essential" for a country to be called democratic, while an average of just 35 percent said the same about procedural components like regular elections, multiparty competition, and freedom of speech (Mattes 2002).

\section{Forced Choices Amongst Proffered Definitions}

This materialist understanding of democracy was echoed in responses to a different set of indicators asked in 2011-2013 as part of a common effort across the regional survey projects that comprise Global Barometers Surveys (Afrobarometer, Latinbarometro, East Asia Barometer, and South Asia Barometer). Rather than asking respondents to rate, or agree or disagree with a series of individual characteristics of democracy, these surveys asked respondents to choose from a set of statements that presented four competing conceptions of democracy: a (1) a socio-economic interpretation that emphasized material equality, full employment, provision of basic necessities or state welfare; a (2) a governance oriented interpretation that focuses on law and order, transparency and efficiency; (3) a freedom oriented interpretation that emphasized political rights such as speech, association and protest; and finally (4) a 
procedural interpretation that featured elections, political parties, legislatures and courts. The first of these four sets read as follows: $:^{13}$

Many things may be desirable, but not all of them are essential characteristics of democracy. If you have to choose only one of the things that I am going to read, which one would you choose as the most essential characteristics of democracy?

Government narrows the gap between the rich and the poor.

People choose the government leaders in free and fair election.

Government does not waste any public money.

People are free to express their political views openly.

Possibly because of the sheer number of statements to which respondents were subjected, no more than 5 percent of respondents provided responses that fit consistently into only one of the potential meanings. But while Africans' understandings of democracy are diverse, they are most likely to choose statements that characterize democracy in terms of the delivery of socio-economic welfare (65 percent provided at least one economic response), and least likely to select statements that refer to political rights or freedoms. Indeed, almost one-half of all respondents (47 percent) never choose a freedom related response, even when given four separate opportunities. Thus, when tapped by open-ended questions that tap a "front-of-the-mind" response, Africans appear to understand democracy as a largely political affair. But closed-ended survey approaches that remind responses of alternative views seem to tap a "latent" understanding of democracy as socio-economic outcomes such as material equality.

What are we to conclude from the sharply contrasting assessments provided by differing approaches? One way is to examine each approaches' ability to explain why some Africans demand democracy, and others do not. We have found that open ended responses are indeed predictive, but only in terms of whether or not respondents are able to offer an opinion. While those who are able to provide any meaning of democracy -- whether procedural or substantive -- possess higher levels of demand, coding responses by whether people provided a political or economic oriented answer fails to discriminate amongst levels of demand (Bratton et al. 2005). In contrast, responses to a multi-item index measuring agreement with closed-ended statements concerning the importance of political procedures provide a very strong predictor of whether people demand democracy (Mattes and Bratton 2007; Mattes et al. 2016). And in some 
countries, as in a special Afrobarometer survey in Ethiopia, we have found that substantive understandings of democracy, as measured across the four sets of statements, leads respondents to over-estimate the extent of democracy in that country (Mattes and Teka 2016).

\section{Where Does Demand for Democracy Come From?}

Economic theories of democratization see demand for democracy emanating from the poor and working class who use it as a tool against the middle class (Boix 2003; Acemoglu and Robinson 2006). There is indeed some evidence for this in that poor Africans are more supportive than the non-poor (Mattes 2008), as are those who are dissatisfied with the performance of the national economy (Bratton et al. 2005). But these effects are minor compared to the role of cognitive awareness: demand is greatest amongst those with higher levels of education, who use news media, and who have higher levels of cognitive engagement with politics. And most studies also find support to be higher in urban areas, and amongst men (as has been found in studies of almost all other regions, see Denemark et al 2016). The cognitive basis of democratic citizenship can also be seen in the finding discussed above: that is, people who understand democracy in political, procedural or liberal terms are more supportive of it (Bratton et al. 2005; Mattes and Bratton 2007), a finding that has been replicated outside of Africa in studies using identical measures (Mattes et al. 2016), or measures of self-expression or emancipation values (Alexander and Welzel 2017; Welzel and Inglehart 2009) as the dependent variable.

While the effect of cognitive awareness demonstrates a strong intrinsic dimension to Africans' demand for democracy, support also has a significant instrumental dimension. But while the common scholarly wisdom expects support to hinge on public satisfaction with the economy (e.g. Przeworski 1995), the instrumental nature of support in Africa tends to be driven by political factors, as much as or more than economic factors, including people's perception of the quality of the electoral process, the level of political freedom, the level of corruption, and the trustworthiness of representative and state institutions (Bratton et al., 2005; Mattes and Bratton, 2007; Mattes 2016; and for similar findings on other continents, see Evans and Whitefield, 1995; Diamond, 1999; Rose et al. 1998; Denemark et al., 2016). 


\section{Demand for Democracy Over Time}

Among the set of 16 countries in which Afrobarometer has conducted at least five surveys since $2002,{ }^{14}$ pro-democratic attitudes followed a steady upward trend from 2002-2003 until 2011-2013, but took a downward turn thereafter. However, as we have already seen, African countries forge distinctive paths. To trace these routes in the most countries and over the longest time period possible, we examine 20 countries for which we have at least three survey observations. We find that these countries divide into three categories, each of which displays a distinct trajectory in demand for democracy over the past decade or more.

FIGURE 5 ABOUT HERE

\section{DEMAND FOR DEMOCRACY OVER TIME}

In the first set of eight countries, demand for democracy has increased steadily over time, leaving each country, as of 2015-2016 with a much more substantial constituency for democracy now than when measurements were first made. At the high end, some countries have seen slow and steady growth in a large cohort of committed democrats. Almost two-thirds of citizens now demand democracy in Senegal (66 percent) and Botswana (62 percent). This social bloc provides a supportive cultural base for deepening democratic institutions and practices. Even at the low end, where only half or fewer citizens are committed democrats, some countries have made impressive recent gains in demand for democracy, as in Namibia ( +32 percentage points), Senegal ( +23 points), Zimbabwe ( +22 points), and Burkina Faso (+22 points). This set of countries is rounded out by Botswana ( +20 points), Cape Verde ( +19 points), Benin (+15 points), and Malawi (+10 points).

The news is less positive in a second set of five countries where demand for democracy has never exceeded 45 percent and in which over-time fluctuations are generally trendless. This group includes South Africa, Lesotho, Madagascar, Mali, and Mozambique). Perhaps the most surprising case in this group is South Africa, where little more than one-third of all adults (just 35percent in 2015) have ever

been committed democrats. One possible explanation is that, since 1994, South Africans have never been inoculated against an extreme authoritarian alternative, for example by experiencing military rule or 
personal dictatorship. That said, a consistently low level of popular democratic demand in South Africa has provided ample room for creeping elite corruption to undermine an otherwise sturdy set of democratic institutions.

A different type of discouraging news characterizes a third set of seven countries. While each of these countries registered early gains in demand for democracy, always exceeding 50 percent (even 78 percent in Zambia) by 2012, this trend reversed sharply, often settling below 50 percent demand for democracy by 2015 . Indeed, this common trend in this set of countries - which includes Uganda, Ghana, Tanzania, Nigeria, Liberia, Zambia, and Kenya - drives the overall continental downturn portrayed in Figure 5. Ghana stands out in this group as an exemplar for recent popular disillusionment with democracy. Until 2012, Ghana was regarded as one of Africa's most promising electoral democracies with its two-party system, peaceful electoral alternations, well-run electoral commission, and court system capable of adjudicating election disputes. Even as these institutions remained formally in place, Afrobarometer surveys indicate that Ghanaian citizens were losing confidence in the democratic system. The country experienced a dramatic 20-percentage-point drop in popular demand for democracy between surveys in 2012 and 2014.

\section{Do Africans Think They Are Getting Democracy?}

Thus far, we have seen that large proportions of Africans appear to want to be ruled democratically, though the picture varies greatly across countries. However, many are inconsistent democrats, sometimes expressing pro-democratic sentiments on some questions while harboring acquiescent or even anti-democratic attachments on others. In this section, we turn to consider whether committed (that is, consistent or "demanding") democrats get what they want. Are those who demand democracy being supplied with it? This question also brings us back again to the question of what Africans understand as democracy and, thus, how they evaluate it. Even though we have found that Africans want to live in a democracy, and evince a basic grasp of the term, an Afro-pessimist might still maintain that they are poor judges of whether elected governments actually govern democratically? Indeed, given the low levels of formal education, and extensive state control of news media that obtain in 
Africa, and the latent materialist understandings of democracy that we have seen above, it might be that many respondents give governments that violate civil liberties and restrict political competition a "pass" as long as they seem to improve domestic welfare.

In order to measure the perceived supply of democracy, Afrobarometer combines respondents' answers to two survey questions:

In your opinion, how much of a democracy is [this country] today? Is it a full democracy, a democracy with minor problems, a democracy with major problems, or not a democracy?

Overall, how satisfied are you with the way democracy works in [this country] today? Are you very satisfied, fairly satisfied, not very satisfied, or not at all satisfied? (Note: Some respondents also respond that their country is not a democracy.)

Respondents are counted as perceiving a supply of democracy if they say that their country is either "a full democracy" or "a democracy with minor problems" and say that they are "very satisfied" or "fairly satisfied" with "the way democracy works." The concept of the supply of democracy is constructed from the average of these two indicators.

The first observation we can make is that - whether measured at the individual level or the country level, or as a current snapshot or a trend over time - the perceived supply of democracy almost always falls short of the popular demand for democracy (with Namibia as a noted exception where, at least in early surveys, people received more democracy than they wanted [Keulder and Wiese 2003]). Compared to the 43 percent who expressed consistently pro-democratic attitudes across 36 countries in 2014-2015, barely more than one-third of African citizens (35 percent) said that incumbent rulers were supplying them with democracy. And the usual caveat applies about cross-country diversity. More than six in 10 Batswana (63 percent), Namibians (63 percent, and Mauritians (63 percent) said they both lived in a democracy and were satisfied with the way democracy worked. At the other end of the spectrum, democratic supply was seen by fewer than two in 10 citizens in Nigeria (19 percent), Mozambique (16 percent, Sudan (16 percent), São Tomé and Príncipe (14 percent), Gabon (10 percent), and Madagascar (9 percent). 
FIGURE 7 ABOUT HERE

THE PERCEIVED SUPPLY OF DEMOCRACY ACROSS COUNTRIES

Trends over time in the perceived supply of democracy (and its two component indicators) adhere to a now-familiar pattern. For the 16 countries with data available over more than a decade (2002-2015), the supply of democracy first trends strongly upward but turns sharply downward after 2012. Thus, just as African citizens are demanding less democracy in the most recent Afrobarometer surveys, they also say that ruling elites are less willing or able to provide it. At the same time, there are important divergence in national trends over time. Examining the 20 countries for which we have at least three surveys since 2002, we find four different broad paths. In the first category, four countries (Mali, Namibia, Tanzania, Senegal) evince increases over time where, even with significant fluctuation, the measured supply of democracy is higher in 2015-2015 than in 2002-2004. A second path is characterized by long term decline (Benin, Kenya, Mozambique, Malawi, Nigeria) over this same period. A third comprises low and steady levels of perceived supply (Burkina Faso, Cape Verde, Lesotho, Madagascar, Uganda, Zimbabwe), and a fourth group simply exhibit trendless fluctuation at different levels (Liberia, Botswana, Ghana, South Africa, Zambia).

\section{FIGURE 8 ABOUT HERE \\ THE PERCEIVED SUPPLY OF DEMOCRACY OVER TIME}

More so than with support for democracy, most political scientists have seen popular satisfaction with democracy as driven almost purely by economic performance (Przeworski 1995; Gunther et al. 2006). However, multivariate analysis of Afrobarometer data has found that political evaluations play an important role, especially popular perceptions of the freeness and fairness of the most recent election, as well as of current levels of political freedom and corruption (Bratton et al. 2005; Greenberg and Mattes 2013; Mattes 2014).

Accordingly, the median African tends to reach similar conclusions about the supply of democracy as expert judges. To obtain the sharpest focus, we focus here on the correlation of popular evaluations of the extent of democracy and four expert based indices (Freedom House's Status of 
Freedom Index, the Polity IV Autocracy-Democracy Score, the World Bank Voice and Accountability Index, and the Mo Ibrahim Institute Index of African Governance's measure of Rights and Participation). Correlations across 35 countries run from .608 (Polity) to .754 (MIIAG). Popular evaluations of the extent of democracy correlate at .691 with the widely used Freedom House Status of Freedom Index.

This is an encouraging finding, suggesting that it is difficult for undemocratic elites to fool their publics about the true state of democracy in their country. But our optimism should be tempered by at least two considerations. First, the proportion in each country who consider the country to be a democracy is itself an average, meaning that many citizens are more critical than the median respondent, but also that many citizens are more forgiving. Second, there are considerable cross-national differences in national proportions, even at the same level of expert judgment. Consider the upper left-hand panel in Figure 9. At the reversed Freedom House score of 3.5 (which would equate to the same score in their actual ratings), which Freedom House considers "partially free" and most analysis term as an "electoral democracy," popular evaluations of democracy range widely from approximately two-thirds or more in Zambia, Liberia and Niger (who rate the country as completely or mostly democratic), to around four-in-ten in Kenya and just one-in-four in Tunisia.

\section{FIGURE 9 ABOUT HERE \\ PUBLIC RATINGS OF THE EXTENT OF DEMOCRACY AND SELECTED EXPERT RATINGS}

\section{Dissatisfied Democrats}

While a great deal of effort has gone into measuring attitudes to democracy around the world, in the conviction that "democracy requires democrats," the actual evidence of the political impact of support for democracy is weak (Mattes, forthcoming). In a notable exception, Lingling Qi and Doh Chull Shin (2011), have found that popular preferences for democracy and rejection of authoritarianism do matter,

but only when that support is matched with a sense of dissatisfaction with the way democracy works. Using a sample of 46 "transitional regimes" which excludes established western democracies, they found that--at the micro level--“dissatisfied democrats" democrats (counted as those who scored above the median on both a scale of support and rejection, and below the median on scale of satisfaction with 
democracy and confidence in government, legislature, and political parties) are more likely than others to report participating in activities such as signing petitions and taking part in boycotts and demonstrations. More importantly, at the macro level, the proportion of dissatisfied was strongly related to subsequent levels of democracy and had an even stronger impact on the extent of change in the level of democracy, even after controlling for a range of country level factors.

In contrast, Africa's dissatisfied democrats are not any more likely to contact public officials or protest, and only slightly more likely to join civic or religious community groups, ${ }^{15}$ or attend community meetings and join with others to address an important issue. ${ }^{16}$ However, they are more likely to support civil liberties, ${ }^{17}$ and see themselves as responsible for holding elected officials accountable between elections ${ }^{18}$ and they are much more likely to support a range of vertical and horizontal limits on government. ${ }^{19}$

More importantly, the data offer at least some macro level evidence that the overall number of dissatisfied democrats shapes that country's prospects for subsequent democratization or backsliding. As displayed in Figure 10, I calculated the percentage of "dissatisfied democrats" (those who were consistent democrats yet scored below the midpoint on the scale of Supply of Democracy) as measured in 20112013 and correlated that score with the extent of democratic regress or progress in the four years following the country survey (as measured by the Freedom House Status of Freedom Index). The evidence yields a modest, but statistically significant relationship between the two variables ( $\mathrm{r}=.351$, $\mathrm{p}=.039, \mathrm{n}=35$ ), and one can observe a fairly strong clustering around the regression line for 30 of the 35 cases. In other words, where the proportion of dissatisfied democrats was relatively large (such as Ivory Coast and Zimbabwe), countries were indeed more likely to move up the Freedom House scale over the next four years. Where that constituency was very small (in places such as Ethiopia, Niger, Tanzania and Egypt), the country was likely to move down the scale. But clearly, the fate of democracy depends on many things other than mass opinion, especially the (anti)democratic commitments of the elite (Mainwaring and Perez-Linan 2013), and the relative power equation between the government and the opposition (McFaul 2002). Thus, five cases fall considerably off the regression line. Tunisia, Madagascar 
and Mali (re)democratized even without a large body of skeptical democrats, and Uganda moved backward even with a relatively large share.

\section{FIGURE 10 ABOUT HERE DISSATISFIED DEMOCRATS AND THE FATE OF DEMOCRACY}

\section{Conclusion}

This review of almost two decades of Afrobarometer public opinion research has detailed a range of findings that carry both positive and negative implications for the state of democracy in Africa. Across a series of different survey questions, large majorities of Africans offer support for various aspects of the democratic regime. However, much smaller proportions of people are consistently democratic across these questions. But once we move beyond continental averages, we saw that pro-democratic attitudes are widespread in some places (like Mauritius and Botswana), but perilously sparse in others (like Mozambique and Lesotho). Moreover, Africans have yet to develop a sense of themselves as active citizens with a role to play in monitoring the actions of government and hold it accountable. And while they articulate a surface understanding of democracy in terms of political procedures, they can be easily reminded and persuaded of alternative economic understandings of democracy. Thus many apparently committed democrats express satisfaction with the progress of only partially democratic regimes.

In many respects, Michael Bratton's 2002 characterization of democratic legitimacy in Africa as "wide, but shallow" still holds true almost two decades later. In some countries, this "shallowness" enables elites to manipulate popular evaluations of the performance of democracy by, for example, emphasizing economic progress over electoral integrity, especially among less educated segments of the population or in countries that have limited exposure to regime alternatives. In others, it provides powercentralizing elites with a great deal of room to close spaces of debate and contestation and restrict rights and liberties, even as they carry on with nominally multi-party elections. What we do not know with any precision, however, is how far autocratic entrepreneurs can push before people who say they prefer democracy and reject authoritarianism will begin to push back. 


\section{References}

Acemoglu, Daron and James Robinson. 2006. Economic Origins of Dictatorship and Democracy. Cambridge: Cambridge University Press.

Ake, Claude. 1996. Democracy and Development in Africa. Washington D.C.: The Brookings Institution.

Bates, Robert. 1994. “The Impulse for Reform in Africa." In Economic Change and Liberalization in Africa, pp. 13-28. Edited by Jennifer Widener. Baltimore: Johns Hopkins University Press.

Boix, Carles. 2003. Democracy and Redistribution. Cambridge: Cambridge University Press.

Bratton, Michael. 2010. “Anchoring the 'D Word' in Africa.” Journal of Democracy 21(4): 106-113.

Bratton, Michael. 2002. Wide But Shallow: Popular Support for Democracy in Africa. Afrobarometer Working Paper, no. 19. East Lansing, Mi.: Afrobarometer.

Bratton, Michael and Nicolas van de Walle. 1998. Democratic Experiments in Africa: Regime Change in Comparative Perspective. Cambridge: Cambridge University Press.

Bratton, Michael and Robert Mattes. 2001. "Support for Democracy in Africa: Intrinsic or Instrumental?" British Journal of Political Science 31: 447-474.

Bratton, Michael and Robert Mattes. 2001. “Africans' Surprising Universalism.” Journal of Democracy 12/1 (January 2001): 105-21.

Bratton, Michael and Robert Mattes. 2009. Neither Consolidating Nor Fully Democratic: The Evolution of African Political Regimes, 1999-2008. Afrobarometer Briefing Paper, no. 67. East Lansing, Mi.: Afrobarometer.

Bratton, Michael, Robert Mattes, and E. Gyimah-Boadi. 2005. Public Opinion, Democracy and Market Reform in Africa. Cambridge: Cambridge University Press.

Dalton, Russell, Doh Chull Shin and Willy You. 2007. "Understanding Democracy: Data From Unlikely Places." Journal of Democracy 18 (October): 142-56.

Denemark, David, Robert Mattes and Richard Niemi. 2016. Growing Up Democratic: Does It Make A Difference? Boulder, Co.: Lynne Rienner Publishers.

Doreenspleet, Renske. 2000. "Reassessing the Three Waves of Democratization," World Politics 52 (April): 384-406.

Greenberg, Ari Paul and Robert Mattes. 2013. "Does the Quality of Elections Affect the Consolidation of Democracy," In Voting and Democratic Citizenship in Africa, pp. 239-252. Edited by Michael Bratton. Boulder, Co.: Lynne Rienner Publishers, 2013.

Gunther, Richard, Jose Ramon Montero and Mariano Torcal. 2006. "Democracy and Intermediation: Some Attitudinal and Behavioral Indicators." In Democracy, Intermediation and Voting On Four Continents, pp. 29-76. Edited by Richard Gunther, Jose Ramon Montero and Hans Jurgen Puhle. Oxford: Oxford University Press.

Keulder, Christian and Tanya Wiese. 2003. Democracy Without Democrats: Results from the 2003 Afrobarometer Survey in Namibia. Afrobarometer Working Paper, no. 47. East Lansing, Mi.: Afrobarometer.

Mainwaring, Scott and Anibal Perez-Linan. 2013. "Lessons from Latin America: Democratic Breakdown and Survival." Journal of Democracy 34(2): 123-137. 
Mattes, Robert. 2018. "Support for Democracy." In Oxford Research Encyclopaedia in Politics. Edited by William Thompson. New York: Oxford University Press, forthcoming.

Mattes, Robert. 2016. "Sub-Saharan Africa," In Growing Up Democratic? Does It Make A Difference, pp. 151-180. Edited by David Denemark, Robert Mattes and Richard Niemi. Boulder, Co.: Lynne Rienner Publishers.

Mattes, Robert. 2014. "Popular Perceptions of Electoral Integrity in Africa," pp. 211-228. In Advancing Electoral Integrity. Edited by Pippa Norris, Richard Frank and Ferran Martinez i Coma. New York: Oxford University Press, 2014.

Mattes, Robert. 2008. "The Material and Political Bases of Lived Poverty in Africa: Insights From the Afrobarometer." In Barometers of Quality of Life Around the Globe: How Are We Doing? pp. 161186. Edited by Valerie Møller, Dennis Huschka \& Alex Michalos. Springer Science Business Media B.V.

Matte, Robert. 2002. "South Africa: Democracy Without the People." Journal of Democracy 13(1): 2236.

Mattes, Robert and Mulu Teka. 2016. Ethiopians' Views of Democratic Government: Fear, Ignorance or Unique Understanding of Democracy? Afrobarometer Working Paper, no. 164. East Lansing, Mi.: Afrobarometer.

Mattes, Robert, Saiful Munjani, William Liddle, Tianjian Shi and Yun-han Chu. 2016. "Parties, Elections, Voters and Democracy." In Voting in Old and New Democracies, pp. 193-229. Richard Gunther, Paul Beck, Pedro Magalhaes and Alejandro Moreno, eds. London: Routledge.

Mattes, Robert and Carlos Shenga. 2013. "Uncritical Citizenship in a Low-Information Society: Mozambicans in Comparative Perspective," In Voting and Democratic Citizenship in Africa, pp. 159-178. Edited by Michael Bratton. Boulder, Co.: Lynne Rienner Publishers, 2013.

Mattes, Robert and Michael Bratton. "Learning About Democracy in Africa: Performance, Awareness and Experience." American Journal of Political Science 51/1 (January 2007): 192-217.

Mattes, Robert, Amon Chaligha, Derek Davids \& Michael Bratton. “Uncritical Citizens' Or 'Patient Trustees? Tanzanians' Views of Political and Economic Reform. Afrobarometer Working Paper, no. 18. East Lansing, Mi.: Afrobarometer, 2002.

McFaul, Michael. 2002. "The Fourth Wave of Democracy and Dictatorship: Noncooperative Transitions in the Post-Communist World," World Politics 54(2): 212-244.

Morlino, Leonardo and Montero, Jose-Ramon. 1995. "Legitimacy and Democracy in Southern Europe." In The Politics of Democratic Consolidation: Southern Europe in Comparative Perspective, Richard Gunther, ed. Baltimore: Johns Hopkins University Press.

Munslow, Barry. 1993. "Democratization in Africa." Parliamentary Affairs 46(4): 487-490.

Nwajiaku, Kathryn. 1994. "The National Conferences in Benin and Togo Revisited." Journal of Modern African Studies 32: 429-447.

Osabu-Kle, Daniel. 2000. Compatible Cultural Democracy: The Key to Development in Africa. Orchard Park, New York, Broadview Press.

Owusu, Maxwell. 1992. "Democracy and Africa: A View from the Village." Journal of Modern African Studies 30(3): 369-396.

Przeworski, Adam. 1995. Sustainable Democracy. Cambridge: Cambridge University Press. 
Qi, Lingling and Doh Chull Shin. 2011. "How mass political attitudes affect democratization: Exploring the facilitating role critical democrats play in the process." International Political Science Review 32(3): 245-262.

Rose, Richard, William Mishler and Christian Haerpfer. 1998. Democracy and Its Alternatives: Understanding Post-Communist Societies. Baltimore: Johns Hopkins University Press.

Schaffer, Frederic. 1998. Democracy in Translation: Understanding Politics in An Unfamiliar Culture. Ithaca: Cornell University Press.

Young, Tom. 1993. "Elections and Electoral Politics in Africa." Africa 63(3): 299-312. 


\section{Endnotes}

${ }^{1}$ The last survey of the 12 countries included in this round of surveys, Tanzania, was not conducted until 2004. All others were done between 1999 and 2001.

27 percent say that "Since elections sometimes produce bad results, we should adopt some other methods for choosing this country's leaders."

${ }^{3} 33$ percent agree that "Political parties create division and confusion: it is therefore unnecessary to have many political parties in [this country]."

${ }^{4} 44$ percent say that "It is more important to have a government that can get things done, even if we have no influence over what it does."

${ }^{5} 12$ percent feel "There should be no constitutional limit on how long the President can serve."

${ }^{6} 27$ percent say "Too much reporting on government mistakes and corruption only harms the country."

${ }^{7} 15$ percent agree that "Since the President represents all of us, he should pass laws without worrying about what Parliament thinks."

${ }^{8} 25$ percent say "Since the President was elected to lead the country, he should not be bound by laws or court decisions that he thinks are wrong."

${ }^{9} 30$ percent say "The President should be able to devote his full attention to developing the country rather than wasting time justifying his actions."

${ }^{10} 63$ percent agree that "Once and election is over, opposition parties and politicians should accept defeat and cooperate with government to help it develop the country."

1138 percent agree that "In our country, citizen should show more respect for authority."

${ }^{12}$ Responses to this question in 2005-2006 were virtually identical; see Bratton and Mattes 2009.

${ }^{13}$ Second Set:

Government ensures law and order.

News media is free to criticize the things that government does.

Government ensures job opportunities for all.

Multiple parties compete fairly in elections.

Third Set:

The legislature closely monitors the actions of the president.

Government provides basic necessities for everyone.

People are free to form organizations in order to influence government.

Public services work well and do not break down.

Fourth Set:

People are free to take part in demonstrations and protests

Politics is clean and free of corruption.

The courts protect ordinary people if government mistreats them.

People receive aid from government when they are in need.

${ }^{14}$ Botswana, Cape Verde, Ghana, Kenya, Lesotho, Malawi, Mali, Mozambique, Namibia, Nigeria, Senegal, South Africa, Tanzania, Uganda, Zambia, and Zimbabwe.

${ }^{15}$ After controlling for gender, age, urban/rural location, and formal education, the partial correlation $=.086$, $\mathrm{p}<=.001$.

${ }^{16}$ Partial correlation $=.073, \mathrm{p}=.001$. 
${ }^{17}$ Partial correlation $=.132, \mathrm{p}=.001$. The measure is a two-item construct combining the belief that people should be able to join any organization of their choice, and that newspapers should be able to publish what they want free of government interference.

${ }^{18}$ Partial correlation $=.132, \mathrm{p}<=.001$.

${ }^{19}$ Partial correlation $=.263, \mathrm{p}<=.001$. The measure is an average index created from responses indicating the belief that people should control government like an employee, that it is more important to hold government accountable rather than a government that gets things done, that multi party competition is necessary to provide choice, that opposition parties should conduct oversight, that parliament should make the laws, that the president should obey the law, and that presidents should be bound by term limits. 